\title{
Multi-level Climate Governance: Polycentricity and Local Innovation
}

\author{
ERNANI CONTIPELLI \\ Professor of Globalization and Environmental Law \\ Regional Community University of Chapecó (UNOCHAPECO, Brazil) \\ ernanicontipelli@gmail.com
}

Reception date: $3^{\text {rd }}$ May 2018 / Accepted: 6th November 2018

\begin{abstract}
The polycentric approach constructed according to Elinor Ostrom's theory is an alternative and pluralistic mode of governance with the objective of reclaiming the former degree of faith of the citizens and communities that had been shaken by the failed climate change initiatives implemented on a global scale. Centering its attention on the lower levels of governance, the polycentric approach offers wide scope for improving the innovative steps that can positively affect the entire global climate system through acquisition of knowledge and learning, especially in the instances of energy transition like the German Energiewende (Renewable Energy Revolution) and the Barcelona Local Energy Agency that are devised for implementation through the active involvement of the local communities. The current study discusses the application of the polycentric approach to multi-level climate governance, particularly highlighting the importance of local innovation as the means to control the global climate crisis, harnessing the collective effort to secure substantial levels of reliability and cooperation between the stakeholders and institutions.
\end{abstract}

RESUM: L'enfocament policèntric construït d'acord amb la teoria de l'Elinor Ostrom és un mode de governança alternatiu i pluralista, l'objectiu del qual és recuperar el grau de confiança dels ciutadans i les comunitats que s'ha vist sacsejat per les iniciatives fracassades sobre el canvi climàtic posades en pràctica a escala mundial. Alhora que focalitza l'atenció en els nivells inferiors de la governança, l'enfocament policèntric ofereix un punt de vista de gran 
abast per millorar els processos d'innovació que poden afectar en positiu tot el sistema climàtic mundial, mitjançant l'adquisició de coneixement i l'aprenentatge, sobretot en els casos de transició energètica (com l'Energiewende alemanya i l'Agència Local d'Energia de Barcelona) concebuts per implementar-se mitjançant la implicació activa de les comunitats locals. Aquest estudi analitza l'aplicació de l'enfocament policèntric en una governança climàtica a molts nivells i que subratlli la importància de la innovació local com a mitjà per controlar la crisi climàtica mundial, aprofitant l'esforç col·lectiu per tal de garantir una bona fiabilitat i cooperació entre les parts interessades i les institucions.

RESUMEN: El enfoque policéntrico construido de acuerdo con la teoría de Elinor Ostrom es un modo de gobernanza alternativo y pluralista, cuyo objetivo es recuperar el grado de confianza de los ciudadanos y las comunidades que se ha visto sacudido por las fracasadas iniciativas sobre el cambio climático puestas en práctica a escala mundial. Mientras focaliza la atención en los niveles inferiores de la gobernanza, el enfoque policéntrico ofrece un punto de vista de gran alcance para mejorar los procesos de innovación que pueden afectar en positivo a todo el sistema climático mundial, mediante la adquisición de conocimiento y el aprendizaje, sobre todo en los casos de transición energética (como la Energiewende alemana y la Agencia Local de Energía de Barcelona) concebidos para implementarse mediante la implicación activa de las comunidades locales. Este estudio analiza la aplicación del enfoque policéntrico en una gobernanza climática a muchos niveles y que remarque la importancia de la innovación local como medio para controlar la crisis climática mundial, aprovechando el esfuerzo colectivo para garantizar una buena fiabilidad y cooperación entre las partes interesadas y las instituciones.

KEYWORDS: Climate Governance Polycentricity - Local Innovation - Energy Transition

PARAULES CLAU: governança climática - policentricitat - innovació local transició energética

PALABRAS CLAVE: gobernanza climática - policentricidad - innovación local -transición energética 
List of Contents: Introduction. 1. Governance and Common Pool Resources. 2. Polycentricity and Climate Change. 3. Multi-level Climate Governance: from the Paris Agreement to Local Innovation. 4. Local Initiatives on Climate Governance and Energy Transition. Conclusion. References.

\section{Introduction.}

As a majority of human-environment interactions happens at several levels, political approaches which consider this natural dimension of the reality and offer an efficient and sustainable use of the common pool resources are the dire need of the hour. From the empirical facts, Elinor Ostrom's concept of polycentricity is designed based on just such human-environment interactions. The theory includes a multi-scale governance system that involves collective management utilizing the innovative actions present at the local and community levels.

To cope with the prevailing global challenges like climate change, this polycentric program and its pluralistic frameworks are a good method of effecting an alternative pattern of governance which encourages experimentation, choice and learning across the several social frameworks that offer greater scope for coping competently with climate change. The objective of this article is to discuss the ways that the polycentric approach can be applied to multi-level governance of climate, focusing on the importance of local innovation as a means of controlling the climate crisis globally, via collective activities to ensure and maintain the degrees of trustworthiness and cooperation between the stakeholders and institutions.

Part one of this article explores the common pool resources and its management, focusing on the differences between the principles of Hardin's Tragedy of the Commons and Ostrom's Governing the Commons as a starting point, for a clearer understanding of the polycentricity approach.

Part two scrutinizes the polycentric approach and its elements, delineating the necessity for alternative forms of governance that can make productive space available at the lower levels for innovation and experimentation and thus effectively handle climate change. It emphasizes the relevance of the collective actions which can increase the degree of trust and 
reciprocity of those individuals who are severely affected by the evident failures of the global negotiations in their attempts to control the climate crisis.

It is significant to sequentially analyze the present logic of the global climate governance effected by the Paris Agreement which focuses on the polycentric approach using a bottom-up process that includes a coordinatelinkage structure limited by a set of comprehensive rules. This results in the building up of relationships between governance at the international, transnational, national, sub-national and local levels.

The final section of this study focuses on the impact of the local drives implemented in terms of climate change and energy transition in decreasing the release of greenhouse gases with the active involvement of the stakeholders and communities. This reveals the benefits of applying the learning process and knowledge acquired to influence the global climate system and draw up sustainable and resilient frameworks. Two case studies were done, viz., the Energiewende (or Germany's Renewable Energy Revolution) which was devised using polycentric principles, and the Barcelona Local Energy Agency with its proposal to optimize the city's environmental programs and to direct the local actions favoring green energy in a response to climate crisis and other global problems.

\section{Governance and Common Pool Resources.}

In the debates conducted over the recent years, it became evident that the bond between the environment and common pool resources-management was first explored by Garrett Hardin, in 1968, in a symbolic article, "The Tragedy of the Commons". He dealt with the devastation faced by society due to the overexploitation of the natural resources and population explosion. Hardin proposed a solution through which the common pool resources in private properties need to be converted, by supporting the owners' rights or by exerting control via robust government regulations, including the implementation of coercive steps and fiscal mechanisms that had received mutual consent.

Hardin considers humankind to be part of a social system that works towards immeasurable profits in a limited world, and that the collective management of the common pool resources would lead to irretrievable ruin because "in a communal property system, each individual enjoys the benefit of 
exploiting the resource to its maximum, while the cost of this increased utilization is spread out over all the users. Consequentially, there is incentive for individual over-exploitation" 1.

Christopher Rodgers states that Hardin's Tragedy of the Commons stated that the incentive to place private profits ahead of the common welfare indicated that the common pool resources would become intrinsically controlled by an inclination towards degradation, resulting in "ruin to all" 2. Hardin supports this argument using the metaphor of a hypothetical free-for-all pasture and where the indiscriminate and collective usage of it ultimately leads to its collapse, because each herdsman is concerned more about his own individual interests rather than the limited natural resources available, and is focused only on numerically increasing his own herds.

Hardin states: "Each man is locked into a system that compels him to increase his herd without limit - in a world that is limited. Ruin is the destination towards which all men rush, each pursuing his own best interests in a society that believes in the freedom of the commons"3.

Using the principle of protecting property rights as a means of producing economic sustainable growth and acting as an incentive to manage the common pool resources, Hardin declared that while any restriction to the freedom of utilizing the common pool resources could be viewed as unfair, it is wiser to be unfair than to devastate the natural resources and drive society towards complete ruin.

Hardin's concepts observed in the "Tragedy of the Commons" censuring the collective actions to maintain wise stewardship of the common pool resources were initially accepted by a few as a scientific law; however, it has slowly gained respect as the conventional wisdom in environmental studies ${ }^{4}$ and has gradually assumed the position of being recognized as an irrefutable paradigm, for several years now.

\footnotetext{
${ }^{1}$ Erin A. Clancy, The Tragedy of the Global Commons, 5, Indiana Journal of Global Legal Studies, 601-619, (1998), p. 604.

2 Christopher Rodgers, Reversing the Tragedy of the Commons - Sustainable Management and the Commons Act 2006, 73 Modern Law Review 461-486, (2010), p. 462

${ }^{3}$ Garrett Hardin, The Tragedy of the Commons, 162, Science 1243 (1968), reprinted in Fred P. Bosselman, Replaying the Tragedy of the Commons, 13, Yale J. on Reg. 391.

${ }^{4}$ David Feeny, Fikret Berkes, Bonnie J. McCay, and James M. Acheson. The Tragedy of the Commons: Twenty-Two Years Later, vol. 18, Human Ecology, 02-19, 1990. p. 02
} 
J. A. Moore's statement, as quoted, is a solid example that shows the significance of Hardin's Tragedy of the Commons model: "Hardin's Tragedy of the Commons should be required reading for all students (...), and if I had my way, for all human beings. It tells us a great deal about ourselves and the cause of many of our problems. It is also an excellent basis for discussion with students" 5 .

Further, Hardin's concepts are now accepted as the essential fundamental basis for resources-management policies, particularly in instances of privatization of a variety of common pool resources, like territorial elements, knowledge and cultural factors and security, besides other important elements, for the local citizens and communities.

Elinor Ostrom, the Nobel Prize winner, recently advanced one of the greatest influential theories challenging Hardin's concept of exclusion. Using experimental data, she declared that small- to moderate-sized groups, and where they have autonomy, draw up their own agreements and have the authority to do so; thus, many user groups have organized themselves to recover from the tragedy ${ }^{6}$, through the sustainable and resilient systems they have developed to manage the common pool resources.

Ostrom uses empirical and systematic research in the field pertaining to the multiplicity of the institutionalized mechanisms available at present, to prove the accomplishment of managing the common pool resources in a decentralized and cooperative manner, emphasizing "self-governance" through collective activities. Ostrom thus showed that while Hardin's theory emphasized reductionism it lacked clear understanding of the dynamics that affect the management of the distinct varieties of open-access resources ${ }^{7}$.

Ostrom, therefore, submitted a method of collaborative, systematic and sustainable management of the common pool resources. She highlighted selfgovernance by the local communities that would enable the citizens to initiate convergent collective actions by refining the open-access and democratic

\footnotetext{
5 J. A. Moore. Science as a Way of Knowing - Human Ecology. American Zoologist 25: 483-637 (1985), p. 602.

${ }^{6}$ Elinor Ostrom "Tragedy of the Commons" in The New Palgrave Dictionaryof Economics. S. Durlauf \& L. Blume, eds. New York: Plagrave Macmillan, p. 02.

7 Álvaro Ramis Olivo. El Concepto de Bienes Comunes en la Obra de Elinor Ostrom, in Ecología Política, num. 45, 116-121 (2013), p. 119.
} 
validity of these resources, with cooperation and coordination of the decisions and policies.

This theory does not focus on the presence or absence of individual property, but rather upon the value of considering specific conditions in order to stimulate cooperation and reciprocity in several local communities, in an attempt to manage the common pool resources. This will ensure their protection and very life and, specifically, circumvent the logic of exclusion observed in Hardin's concepts.

Robert Axelrod supported the view that Ostrom's inputs were made possible as she had reframed the debate on Hardin's Tragedy of Commons, which had offered alternatives to those properties considered as private vs. central authority, where the decisions were taken by one or more individual and independently functioning decision-makers. However, in the real world settings Ostrom's views showed that users of the common pool resources who repeatedly interacted among themselves often constructed institutions that effectively monitored and disciplined the free riders, thus accomplishing efficient and sustainable utilization of the resources ${ }^{8}$.

From this sequence of concepts, the relationship between the neoliberal literature and the principles underlying Hardin's Tragedy of the Commons becomes clear, as both examine the case that in collective management, the stakeholders seek only the individual benefits, inevitably leading to the depletion of the natural resources. However, this theory fails to constitute the empirical facts of our reality, as challenged by Ostrom. The collectively managed natural resources - similar to the case of the indigenous territories are usually better protected and sustainable than the privatized ones which are subject to the law of maximization of profits ${ }^{9}$.

Ostrom acknowledged the presence of difficulties in the management of the common pool resources, and considered their restriction and the potential competition prevailing among their users as variables that could result in their ruin. She also understood that when multiple individuals utilize the common-

\footnotetext{
${ }^{8}$ Robert Axelrod. Review: Beyond the Tragedy of the Commons. A Discussion of Governing the Commons: The Evolution of Institutions for Collective Action by Elionor Ostrom. Perspectives on Politics, vol. 8, n. 02, pp. 569-593 (2010), p. 580.

${ }^{9}$ Luis Gonzales Reyes, Bienes Comunes, in Zubizarreta, J. H., González, E. y Ramiro, P. Diccionario Crítico de Empresas Transnacionales. Claves para enfrentar el Poder de las Grandes Corporaciones. Barcelona: Icaria Editorial (2012).
} 
pool resources, finite quantities of resource units arise in which one individual's usage reduces the number of resource units for the others to use ${ }^{10}$.

In fact, common pool resources management includes the issue of collective actions and requires clear analysis based on its variables (viz., group size, composition, characteristics of the resources, relationship with the external powers) and institutional arrangements that can construct a theoretical basis to provide an explanation for why some users of the resources, over time, can organize and self-govern the management of a resource in a sustainable manner and why the others neither succeed or nor even make the effort ${ }^{11}$.

Ostrom showed that one can definitely organize a series of design principles that are representative of the sustainable management of the governance system of the common-pool resources, involving its users in collective actions that will lead to strong and successful self-governance institutions being established. Ostrom described these design principles as an "element or condition that helps to account for the success of these institutions in sustaining the (common-pool resource) and gaining the compliance of generation after generation of appropriators to the rules in use" 12 .

Ostrom proposed the eight design principles listed here: 1) Clearly Defined Boundaries, identifying the individuals who possess the rights to utilize a particular resource and the resource boundaries; 2) Compatibility between the rules allocating benefits and the ones assigning costs, acceptable as impartial and legal by every participant; 3) Collective-Choice Arrangements for modifications of the operational rules of regular usage of the resources by the individuals affected by them; 4) Monitoring monitors who actively inspect the conditions of the common-pool resources and the appropriator's activities are answerable to the appropriators and/or are the appropriators themselves; 5) Graduated Sanctions, where an appropriator who is a repeated offender and whose actions are brought to notice, is eventually penalized to the extent that rule-breaking loses its appeal; 6) Conflict-Resolution Mechanisms, in instances where disputes regarding the interpretation of a rule that restricts the

\footnotetext{
${ }^{10}$ Xavier Basurto and Elionor Ostrom. The Core Challenges of Moving Beyond Garret Hardin. Journal of Natural Resources Policy Research, vol. 01, n. 03, 255-259 (2009), pp. 256.

${ }^{11}$ Idem, pp. 256.

12 Elinor Ostrom. Governing the Commons: The Evolution of Institutions for Collective Action, Cambridge University Press, New York (1990), p. 90.
} 
appropriation activities or necessitates input resources are not settled in an economically feasible and organized way, the appropriators may be reluctant to adhere to the rules because of the manner that "others" explain them to suit their own ends; 7) Minimal Recognition of the Rights to Organize, the rights of appropriators to design their own institutions are recognized by the external governmental authorities; 8) Nested Enterprises, in the case of larger resources involves several participants; nested enterprises that range in size from small to large allow the participants to resolve manifold issues involving different scale economies ${ }^{13}$.

Ostrom discerned the pertinent parts played by the concepts of the current market and state, based on the classical economic theories. However, the huge variety of institutional arrangements that have been designed for the governance, provision, and management of the common-pool resources only serve to emphasize the inadequacy of this "dichotomous view of the world", demonstrating that by the mid-twentieth century, the predominant method of research was merely an attempt to try to mold the world into simple models and critique the institutional arrangements that failed to conform ${ }^{14}$.

\section{Polycentricity and Climate Change.}

Ostrom's theory offers effective substitute solutions for governing the common-pool resources which surpass those suggested by the traditional theories of State or privatization, and which are not necessarily the only answers to this issue. Many times, these theories presented options that involved the devastation of the natural resources, ecosystems, native populations, species and genetic diversity, inflicting actual harm to the social capital of the local communities ${ }^{15}$.

Ostrom's alternative governance system accentuated polycentricity which includes the actions of multiple and lower levels of governance as an analytical means of global change. The polycentric system involves the spreading out of

13 Elinor Ostrom. Common-Pool Resources and Institutions Toward a Revised Theory. Handbook of Agricultural Economics, vol. 02, Edited by B. Gardner and G. Rauser (2002), p. $1330 / 1333$.

${ }^{14}$ Elinor Ostrom. Beyond Markets and States: Policentric Governance of Complex Economic Systems. American Economic Review, 100, 641-672 (2010), p. 642.

${ }^{15}$ Leticia Merino Pérez. Perspectivas sobre la Gobernanza de los Bienes y la Ciudadanía en la Obra de Elinor Ostrom, in Revista Mexicana de Sociología n. 76 (especial), 77-104 (2014). 
the governing authorities at different levels, rather than focusing on a monocentric unit. Each unit functions across overlapping jurisdictions, operating within quite a wide autonomy, implementing norms and rules within a specific domain (like family, firm, local government, local government networks, or even across a state or province, region, national government, or international jurisdiction $)^{16}$.

From the empirical perspective, particularly some types of monocentric governance concerned with climate change (like unilateral state action) are rife with structural biases and obstacles that block the development of effective policy. In fact, polycentricity involves quite the opposite logic, as its objective is to follow a unique and pluralistic path that balances the potential costs of including multiple and frequently overlapping domains of governance and their advantages which are linked to experimentation, learning, trust building and context sensitivity ${ }^{17}$.

Vincent Ostrom, Charles Tiebout and Robert Warren presented an epic article, "The Organization of Government in Metropolitan Areas: A Theoretical Inquiry" (1961), introducing the term 'polycentricity', and explaining it as a system "of many autonomous units formally independent of one another, choosing to act in ways that take account of others, through the process of cooperation, competition and conflict resolution"18.

The polycentric system is thus defined as the management of social activities within multiple interrelated units, which should however, be initiated from individual centers when organizing its own actions and relationships with the other units working to achieve a common goal. Vincent Ostrom and his colleagues indicated in that article the example of the US metropolitan areas, which under definite conditions can construct improved methods of community management than the earlier prevailing standard form of centralized structure ${ }^{19}$.

16 Elinor Ostrom. Polycentric Systems for Coping with Collective Action and Global Environmental Change, Global Environmental Change 20, 550-557 (2010), p. 552.

17 Ross Gillard, Andrew Gouldson, Jouni Paavola and James Van Alstine. Can national blockages accelerate the development of polycentric governance? Evidence from climate change policy in the United Kingdom. Global Environmental Change, 45, 174-182 (2017), p. 175.

${ }^{18}$ Vicent Ostrom, Charles M. Tiebout and Robert Warren. The Organization of Government in Metropolitan Areas: A Theoretical Inquiry. American Political Science Review 55 (4), 831-842 (1961).

${ }^{19}$ Marcel J. Dorsch and Christian Flatchsland. A Polycentric Approach to Global Climate Governance. Global Environmental Politics, Vol. 17, Number 2, 45-64 (2017), p. 48. 
Thus, polycentricity encourages beneficial interactions among the several governance units, which include the coordination of their own actions with a reciprocal and cooperative mindset and which desires to accomplish reciprocal works. The logic involved in this system is completely divergent from the concept of a central authority when potential differences need to be resolved between the various actors, and is governed by rule of law and a series of overarching regulations. According to Vincent Ostrom's essay (1990), the polycentric order was "one where many elements are capable of making mutual adjustments for ordering their relationships with one another within a general system of rules, where each element acts with independence of the other elements" 20 .

Therefore, the actions of the local communities (which include their autonomy to institute rules, as well as their ability to monitor and approve, and their capacity for face-to-face communication) $)^{21}$ embrace conclusive factors to determine the success or failure of the common-pool resources governance using the polycentric approach, as they offer the potential to maximize the advantages of the actions under the control of a set of comprehensive rules that ensures mutual tasks are accomplished and any dispute is adequately resolved.

When "global problems" like climate change are the focus, they refer to the cumulative outcome of the actions of individuals, families, small groups, private firms, or even local, regional, and national governments, which require collective actions that will raise the confidence and reciprocity levels of the individuals concerned, to identify answers for their actions, with the willing cooperation of the citizens ${ }^{22}$.

"Global problems" involves an important factor, viz., "time" which is the one variable that is not easily negotiable at the international level and which can frustrate the chances of identifying a fitting solution in time to avert serious backlashes to society. Further, global negotiations require support from several

\footnotetext{
${ }^{20}$ Vicent Ostrom. Polycentricity - Part . In Polycentricity and Local Public Economics. Ed. Michel Mc Ginis, 52-74. Ann Arbor: University of Michigan Press (1999).

21 James M. Walker, Roy Gardner, Andrew Herr and Elionor Ostrom, Collective Choice in the Commons: Experimental Results on Proposed Allocation Rules and Votes. The Economic Journal, 110, 212-234 (2000), pp. 212/213.

22 Elinor Ostrom. Polycentric Systems for Coping with Collective Action and Global Environmental Change, Global Environmental Change 20, 550-557 (2010), p. 550.
} 
types of efforts at the national, regional, and local levels, for effective functioning. In this context, Ostrom draws attention to the fact that while several outcomes of climate change are global, what actually causes them takes place on a much lower level. To explain this she introduced the catchy phrase, "Think Globally, Act Locally"23.

Ultimately, successful institutions of global governance are inescapably polycentric because no single global or international system can accomplish anything without the support of national legislations for implementation as well as monitoring at the national and sub-national levels and enforcement activities which even involve the active involvement of non-governmental groups at the local level ${ }^{24}$.

Limited on the one hand by the subsidiarity principle and defined by the concurrence of multiple circumstances on the other, the polycentric mode recognizes that the lowest level of power offers better government services for the citizens and community. They are more effective in applying their policies because the players can pick and select only such producers and providers which best suit each specific issue they encounter ${ }^{25}$.

In light of this analysis, Ostrom disagreed with the conventional theory of collective action, and upscaled it in terms of climate change, emphasizing the behavioral framework of human action and the significance of the "information" and the part it plays in a particular setting to win the confidence and reciprocity, plus improve the sustainable cooperation among the individuals and groups via solutions of "self-organization" of the common-pool resources, from the small to medium level ${ }^{26}$.

According to Ostrom the major variables that strengthen the potential success of a self-organized system dealt with the resolution of the issues arising from collective actions, and are as listed: "1) reliable information regarding the immediate and long-term costs and benefits of the actions is available; 2) the individual participants recognize the common pool resources

${ }^{23}$ Elinor Ostrom. A Multi-Scale Approach to Coping with Climate Change and Other Collective Action Problems. Solutions 1 (2): 27-36 (2010), p. 28.

${ }^{24}$ Daniel H. Cole. From Global to Polycentric Climate Governance. Climate Law 2, 395-413 (2011), p. 396.

${ }^{25}$ Daniel H. Cole. Advantages of a Polycentric Approach to Climate Change Policy. Nature Climate Change, vol. 05, (2015), p. 114.

${ }^{26}$ Elinor Ostrom. A Multi-Scale Approach to Coping with Climate Change and Other Collective Action Problems. Solutions 1 (2): 27-36 (2010), p. 30. 
as vital to their own accomplishments and focus on a long-term time horizon; 3) earning a name for being a trustworthy reciprocator is crucial to the participants; 4) communication is possible between individuals and a least a few of those involved; 5) informal monitoring and sanctioning are possible and appropriate; and 6) social capital and leadership are present, in connection with prior successes in resolving joint problems" 27.

Thus, the choice to include small- to medium-scale governance units and their information networks and monitoring intensities constructed on collective action shows greater effectiveness in handling climate change ${ }^{28}$. This is because such a multi-level perspective induces experimental efforts at the various levels and gives a comparative analysis of the findings in specific ecosystems, to facilitate estimating the cost and benefits of the strategies, strengthening the resolve to identify the means of minimizing individual emissions and the trust that others are also accepting responsibility ${ }^{29}$.

While recapitulating her discoveries on applying the polycentric approach to the issues of providing public goods and preserving the common pool resources as the causes of climate change, Ostrom realized that this system offers a vast scope for experimentation, choice, and learning across social organizations. She also saw it as means of boosting innovation, adaptation, trustworthiness, degrees of cooperation by the participants, and the accomplishment of more advantageous, equitable, and sustainable results at multiple levels ${ }^{30}$.

Indeed, it is clearly evident that not even one country was able to successfully minimize its greenhouse gas emissions, and neither was a substantial global agreement formulated thus far to accomplish this task. Sadly, the United Nations Framework Convention on Climate Change (UNFCC) and the Kyoto Protocol too have failed due to the unreliable strategies and absence of coordinate implementation in engaging the different levels of control, as well as the groups and individuals in the battle against climate crisis.

\footnotetext{
${ }^{27}$ Idem, p. 31.

28 Jale Tosun and Jonas Schoenefeld. Collective Climate Action and Networked Climate Governance. WiREs Clim Change 2017, 8: e440, p. 04.

${ }^{29}$ Elinor Ostrom. A Polycentric Approach for Coping with Climate Change. Policy Research Working Paper 5095, World Bank, 2009, p. 11.

${ }^{30}$ Daniel H. Cole. Advantages of a Polycentric Approach to Climate Change Policy. Nature Climate Change, vol. 05, (2015), p. 115.
} 
Ostrom also propounds that when the control measures are focused only at a global level, it becomes harder to raise the confidence levels that the citizens and institutions need to build with other citizens and firms on the other half the globe, and who are implementing measures akin to those being done at home. Ostrom declares, "when participants fear they are being 'suckers' for taking costly actions while others enjoy a free ride, more substantial effort is devoted to finding deceptive ways of appearing to reduce emissions while not actually doing so"31.

Daniel $\mathrm{H}$. Cole also expressed his apprehensions regarding the poor advancement made in climate negotiations on a global scale, assessing that after "more than 20 years of UN climate meetings is that little mutual trust has developed so far. Indeed, a review of contemporaneous accounts from recent global climate meetings indicates continuing high levels of distrust, represented not only by lack of progress on mitigation but also by well-publicized conflicts among parties"32.

In light of these facts, it is feasible to pose the queries related to local innovation and the ways this specific level of governance is tackling the global challenges. It must be checked to see if the communities are being offered the opportunity to partake in establishing the decision-making process of sound policies, involving both citizens and institutions in a cooperative atmosphere of confidence and reciprocity within a polycentric framework, in order to restrain the climate crisis and control global warming.

\section{Multi-level Climate Governance: from the Paris Agreement to Local Innovation.}

To get a good handle on the parts played by local innovation utilizing the polycentric approach to cope with climate change, the dynamics of the multilevel climate governance must certainly be analyzed. Special attention must be paid to the concerns and existing differences related to the concepts of hierarchy and polycentricity, and the ways they act within the framework of the

\footnotetext{
${ }^{31}$ Elinor Ostrom. A Multi-Scale Approach to Coping with Climate Change and Other Collective Action Problems. Solutions 1 (2): 27-36 (2010), p. 33.

32 Daniel H. Cole. Advantages of a Polycentric Approach to Climate Change Policy. Nature Climate Change, vol. 05, (2015), p. 117.
} 
relationship existing among the myriad institutions involved in climate governance.

One needs to first acknowledge that multi-level governance functions at different levels, with horizontal, vertical and diagonal relationships existing between the institutions, levels of connections and the respective geographical regions. It was Daniel Bodansky and colleagues who described multi-level governance in terms of horizontal relationships existing between institutions at the identical hierarchical or geographical level; as vertical relationships between institutions on varying levels, and as diagonal ones present between them on different levels in different countries ${ }^{33}$.

Thus, the multi-level climate governance aims at investigating the potential relationships that can exist between specific levels of governance and to construct connections with international, transnational, national and subnational initiatives, contouring them within the framework of the global climate system so as to ensure achieving a common goal, which is to control the current climate crisis.

These relationships are distinguishable as two ideal categories: hierarchical, in which certain institutions are superior to the others, most frequently seen among the vertically related institutions; or polycentric, in which multiple nodes of authority are present, possessing the overlapping jurisdiction but without a hierarchical order. Normally, while the jurisdiction of the international institutions can overlap, none is superior to the other, true to the pattern of the polycentric system ${ }^{34}$.

As specified earlier, the hierarchical and polycentric orders are ideal models, with both of their elements being present in several systems. Therefore, the identification of the polycentric elements in one system includes an interpretation task which can contextualize its dynamics and the logic supporting the relationship present between the institutions.

At present, the logic undergirding global climate governance has been modified. From the time of the Paris Agreement, the polycentric approach has been adopted to handle climate change, replacing the monocentric dynamics

\footnotetext{
${ }^{33}$ Daniel Bodansky, Jutta Brunnée and Lavanya Rajamani. International Climate Change Law. Oxford University Press (2017), p. 260.

${ }^{34}$ Idem, p. 261.
} 
evident in the Kyoto Protocol. The Paris Agreement acknowledges the general presence of domestic policies which drive climate action and permit countries to set up their own goals for minimizing the greenhouse gas emissions.

Robert Falkner emphasized the failed efforts to push for a global deal on mandatory reductions in emissions, suggesting "the new regulatory approach adopted by the Paris Agreement managed to transform the international negotiations from a distributional conflict over legally binding targets into a bottom-up process of voluntary mitigation pledges. By allowing countries to determine their mitigation efforts independently, it removed a key barrier that held back the post-Kyoto negotiations" 35 .

The Nationally Determined Contributions (NDC) is the specific key that facilitates a clear understanding of the polycentric logic incorporated into the Paris Agreement. They reflect the actions that each country professes to implement and states its long-term aspirations and efforts to respond to climate change, offering targets connected to reduction, adaptation and methods of implementation (viz., finance, technology, capacity building and transparency).

In fact, the rogue differences prevalent among the countries to achieve their own NDCs, in light of their specific social and economical states, reiterates the significant part that polycentricity plays as an approach that permits each country to adjust and contextualize its own policies that suit the ability of one nation to continue its own development but simultaneously, handle the issue of climate change.

The submission process of the Intended Nationally Determined Contributions just before the $21^{\text {st }} \mathrm{COP}$ in Paris and the future review of the mechanisms proposed by the Paris Agreement demonstrate that among the many features of the polycentric approach to climate governance is the inclusion of "trust catalysts". This enables the intentional construction of confidence among a limited number of actors, in terms of relational structures, emphasizing the value of face-to-face communication as well as acting as a deterrent to free-riding ${ }^{36}$.

\footnotetext{
${ }^{35}$ Robert Falkner. The Paris Agreement and the New Logic of International Climate Politics. International Affairs, 92, 1107-112 (2016), p. 1124.

36 Marcel J. Dorsch and Christian Flatchsland. A Polycentric Approach to Global Climate Governance. Global Environmental Politics, Vol. 17, Number 2, 45-64 (2017), p. 57.
} 
In their analysis of the logic of international climate collaboration, Robert O. Keohane and David G. Victor highlighted the necessity for including the most promising techniques (viz., climate clubs, coordinated research, pledge and review, coordinated national actions with substantial benefits accorded to the states implementing the action) in the polycentric mode. This suggests that rather than focusing on a single organization, the final outcome could involve a combination of strategies devised partly to handle only the national or local issues. They stated: "For years, this complex and decentralized outcome has been seen as something to be feared, but our analysis of coordination and cooperation suggests that it could be essential. States should cooperate where cooperation is too difficult or where universal participation is desirable; and probe experimentally to seek to expand the boundaries of feasible cooperation. Since no single path is likely to be globally effective on its own, a multiplicity of actions should be taken"37.

Certainly, the failed monocentric-based approach of the Kyoto's model of governing, focused on legally binding quantified emission goals, demonstrates the need to adopt a polycentric method in which national ambitions are formulated, reported, and updated over time, through a series of procedural obligations, entailing a revision of the previous consolidated assumptions in the field of climate governance. This should be done to foster initiatives from multiple governing units, as an opportunity for the development of learning and knowledge processes with regard to what works best in different domains.

In this context, Nation-states recovered their pivotal role in the international order, at least in a given issue area, presenting themselves as key institutions for the implementation of mitigation and adaptation actions through the NDCs. As "supportive actors" that ensure climate actions and sustainable development, the Nation-states can influence patterns of consumption and production, encouraging investment in low-carbon technologies and other decisive actions, which highlight the relevant part they play among the vast number and types of actors in the global climate governance arena ${ }^{38}$.

\footnotetext{
${ }^{37}$ Robert O. Keohane and David G. Victor. Cooperation and Discord in Global Climate Policy. Nature Climate Change 6, (2016), p. 11.

38 Joana Setzer and Michal Nachmany. National Governance: The State's Role in Steering Polycentric Action, p. 48/49. In Andrew Jordan, Dave Huitema, Jonas Schoenefeld, Harro Van
} 
The Nation-states' role in polycentric climate governance can be achieved through intervention, by the establishment of regulatory frameworks, in an attempt to define patterns of social behaviour addressed to cope with climate change, with the participation of the legislative, executive, and judiciary branches of government, and in mobilization by sharing their power with subnational units of the state and non-governmental actors, so as to stimulate them to collaborate in the implementation of policies expressed in the NDCs and to move toward a low-carbon economy.

The polycentric approach of handling climate change enhances the role of the distinct institutions from the international to the lower scales, justifying their active involvement in producing, minimizing, and adapting strategies for the different levels of governance.

For instance, increasing acknowledgment of the crucial role of the national initiatives in dealing with climate issues, especially post the Paris Agreement, has become a reality, and constitutes a part of the present dynamics and logic that underlies the international climate system, and attempts to create a balance between global targets and domestic expectations, for action.

One of the criticisms leveled against the polycentric approach in handling climate change, points to the fragmentation of the system and its potential to include confusion, replication of efforts, forum shopping, and even disputes ${ }^{39}$. For example, local policies, which at times can have conflicting intergovernmental interdependencies can be incorrectly mistaken for national strategies $^{40}$.

To circumvent this drawback, an overarching set of shared rules and regulations opens up a way for the self-organized units to coordinate, thus averting contradicting actions and low effectiveness. The polycentric government system involves the top-down institutions which is vital to its formation and maintenance. This facilitates multiple participants to coordinate

Asselt and Johanna Forster (eds) Governing Climate Change: Polycentricity in Action? Cambridge University Press (2018).

39 Daniel Bodansky, Jutta Brunnée and Lavanya Rajamani. International Climate Change Law. Oxford University Press (2017), p. 263.

${ }^{40}$ Kirsten Jörgensen, Anu Jogesh and Arabinda Mishra. Multi-level Climate Governance and the Role of the Subnational Level. Journal of Integrative Environmental Sciences, 12:4, 235-245 (2015), p. 237. 
their activities, resolve disputes between the lower level units and mutually exchange data regarding their successful strategies, and perhaps even transfers, from one local setting to another ${ }^{41}$.

The overarching set of rules, therefore, creates conditions that promote self-organization among the local communities, while assuring the coordination of the entire system of initiatives and guaranteeing their execution by authorizing any departure from compliance. These rules also supply a lot of information which facilitate settling disputes and fostering negotiations among the governing units at the lower levels ${ }^{42}$.

Of course, the existence of overarching rules related to polycentric approach can be derived from a specialized international regime that influences multi-scale governance units and their actions as multipliers of pledges addressed to cope with global problems. Moreover, in a globalized world, where most of the original institutional and regulatory functions of the Nation-states are taken outside their borders, the efforts to construct a narrative based on the idea of a scheme of comprehensive values, principles and rule within a polycentric approach has to be centred on the capacity to promote a convergence of policies, fostering innovation and spreading effects positively through the whole climate governance system, as successful experiments as well as failures, both play relevant roles in this process of knowledge and learning.

To summarize, polycentric systems are characterized by multiple centres of decision-making authority with overlapping jurisdictions that do not stand in hierarchical relationship; instead they compete, and at the same time, cooperate with each other. Their interactions are developed through a process of mutual adjustment with spontaneous collaboration and learning from one another, generating a regularized pattern of an overarching social $\operatorname{order}^{43}$.

\footnotetext{
41 Thomas Bauwens. Polycentric Governance Approaches for a Low-Carbon Transition: The Roles of Community-Based Energy Initiatives in Enhancing the Resilience of Future Energy Systems. In Labanca, N. (ed), Complex Systems and Social Practices in Energy Transitions: Framing Energy Sustainability in the Time of Renewables, pp. 119-145, London: Springer, 2017, p. 126

42 Benjamin K. Sovacool. An International Comparison of Four Polycentric Approaches to Climate and Energy Governance. Energy Policy, 39, 3832-3844 (2011), p. 3842/3843.

${ }^{43}$ Andrew Jordan, Dave Huitema, Jonas Schoenefeld, Harro Van Asselt and Johanna Forster. Governing Climate Change Polycentrically: Setting the Scene, p. 11. In Governing Climate Change: Polycentricity in Action? (2018) Cambridge University Press.
} 
This polycentric approach enables the United Nations Framework Convention on Climate Change (UNFCCC) to effect significant governance, as it presents the substantive and procedural factors that represent goals and objectives of an "overarching rule" 44 that binds the other regulations, norms, values and policies related to climate change, to ensure that broader goals are achieved, settle disputes between the different institutions and individuals and avert potential dominance by any of the participant players.

In this context, the decision-making taken by the Conference of the Parties (COPs) acquires expressive, operational and legal significance in the climate regime, enriching and expanding the normative core of the regime by fleshing out provisions, reviewing the adequacy of existing obligations, and launching negotiations to adopt further agreements. It means, the COPs' decisions symbolize a constant work-in-progress to outline the institutional architecture of the international climate regime and to achieve the common purpose of the planetary fight against climate change., innovating and promoting laboratories for experimentations in order to foster convergence of interests and actions among multiple actors (governmental and nongovernmental) and stakeholders.

Certainly, these dynamics are characterized by turning points, in correspondence with schemes derived from political negotiations involving the driven forces that act in the global climate governance. At present, the turning points could be represented by the distinct logic of the Kyoto's model of governing, focused on a monocentric and centralized approach, and the Paris Agreement, attempt for a decentralized framing and the polycentric features of the system in which a variety of governance levels (local, regional, national, supranational, international), public and private actors, and fora are recognized as driving forces of climate action in their own right ${ }^{45}$.

As part of the scheme of overarching rules headed by the UNFCCC, the Paris Agreement reforms and provides guidance for the evolution of the framework of the international climate regime, attributing normative validity and acceptance to it, with the engagement of governments and societal actors

\footnotetext{
${ }^{44}$ Sebastian Oberthür. Reflections on global climate politics post Paris: Power, Interests and Polycentricity. The International Spectator, 51 (2016), 80-94.

${ }^{45}$ Sebastian Oberthür. Reflections on global climate politics post Paris: Power, Interests and Polycentricity. The International Spectator, 51 (2016), 80-94.
} 
increasing its polycentric institutional architecture, as well as enhancing the potential for its implementation and related behavioral adaptations.

Thus the UNFCCC acts as an overarching ruling body and in keeping with the logic undergirding the Paris Agreement, augments the advantages of the polycentric approach. The overlapping jurisdictions which maximize the potential of multiple institutions to handle climate change, is particularly seen at the local levels, where their role is more that of a laboratory with experimentations to produce innovative outcomes that can be models for other jurisdictions to implement at the same or different levels. This storehouse for potentially transformative concepts at the lower levels is linked to the higher levels of national and global climate processes, particularly, within the bounds of the overarching rules.

Based on the polycentric approach, the UNFCCC, as an overarching set of shared values, principles, and rules, opens up a way for the self-organized units to effectively coordinate at the societal level, thus averting contradicting actions and low effectiveness and boosting the climate pledges, by helping to converge the efforts of multiple actors involved in handling this issue ${ }^{46}$.

The polycentric approach for handling climate change enhances the role of the institutions at the local levels, justifying their active involvement in producing minimizing and adapting strategies for the other levels of governance (regional, national and global), thus acting as a means of involving the stakeholders in the communal assignments. The increasing acknowledgment of the crucial role of the local initiatives in dealing with climate issues has become a reality, and constitutes a part of the present dynamics and logic that underlies the climate system and attempts to balance global targets and domestic expectations for action.

\section{Local Initiatives on Climate Governance and Energy Transition.}

Multi-governance systems enable innovative actions that aim at handling climate change to be identified within a polycentric approach, especially, at the lower levels of governance. These are the best levels at which the mitigation pledges can be promoted via the inclusion of carbon-free energy policies,

46 Daniel H. Cole. From Global to Polycentric Climate Governance, p. 412. Climate Law, 2, 2011, pp. 395-413. 
involving the local community and stakeholders in the hunt for answers to this global issue.

Certainly, the cities and local communities are necessarily responsible for introducing and encouraging climate initiatives as they play a role in relevant spheres of policy like housing and household energy consumption, transport, regulations and infrastructure, land use and urban planning or waste disposal, besides others. In fact, the most crucial initiative is being responsible for the local energy supply, where the cities across Europe for instance, can exert a powerful influence, because $80 \%$ of the emissions of greenhouse gases in this part of the world are connected with urban activities ${ }^{47}$.

To show the possibilities of implementing the polycentric approach, Ostrom's studies highlight the advantages of acquiring local knowledge, as well as learning from those also engaged in the trial-and-error learning exercise. Over time, these provide techniques for mutual monitoring, learning and adaptation of the improved strategies ${ }^{48}$.

The findings from these acquisition of knowledge and learning processes in spheres like energy transition offer a sustainable and resilient framework for the entire system, boosting the achievements of multiple units which act as parallels in different regions, specifically, at the local level that has the potential of adjusting the innovative policies to best suit its own context.

According to Thomas Bauwens, there are three obstacles which weaken the resilience of the governance systems to stimulate low-carbon transition: "the collective-action problem in the diffusion of more sustainable energy technologies and practices, the lack of trust in conventional energy actors and the existence of strong vested interests within the energy industry". Hence, the polycentric approach is centered on the community-based energy transition enterprises, which enable them to surpass the impediments mentioned, developing the institutional resilience of the energy system towards the renewable resources ${ }^{49}$.

\footnotetext{
${ }^{47}$ Martin Jänicke. Accelerators of global energy transition: horizontal and vertical reinforcement in multi-level climate governance. Potsdam: Institute for Advanced Sustainability Studies, 2013, p. 12.

48 Elinor Ostrom. Polycentric Systems for Coping with Collective Action and Global Environmental Change, Global Environmental Change 20, 550-557 (2010), p. 552.

49 Thomas Bauwens. Polycentric Governance Approaches for a Low-Carbon Transition: The Roles of Community-Based Energy Initiatives in Enhancing the Resilience of Future Energy
} 
Benjamin K. Sovacool in his support for the polycentric approach and its ability to integrate the strengths of the local and global actions in the instances dealing with energy transition demonstrated that the policy preferences tend to be more compatible within the smaller units than across the broader ones. In fact, they open up more choices for the citizens to implement a set of regulations and, simultaneously, involve the local actors to conform to a common group of goals and eventually enforce them at the global level ${ }^{50}$.

Both scholars reiterate the role of the state from the perspective of polycentric governance as being a "supportive state". Thus, the central state under the guidance of the polycentric governance plays a pivotal part in ensuring that great steps are taken in handling global climate change, through intervention and investment in decisive actions to achieve the objectives of increased production and consumption of sustainable energy, as well as to share this power with the other players ${ }^{51}$.

For example, the escalating awareness regarding the notion of sustainable cities confirms the present inclination to emphasize the importance of governance at the lower levels, especially, when dealing with global environmental issues like climate change. According to Harriet Bulkeley and Michele Betsill, there are four reasons why local governments exert some influence on greenhouse gas emissions, supporting the national governments in achieving the goals that they have set internationally: Due to the rapidly growing urban face of the global populace, cities have become hubs of high energy consumption and waste production, and it is the local authorities who can exert some level of influence over these emissions. It is the local authorities who can implement the complex sustainable agenda. Again, it is the local authorities who play crucial roles in the urban locales by coordinating the actions between the different players, thus involving the community in the policy programs.

Systems. In Labanca, N. (ed), Complex Systems and Social Practices in Energy Transitions: Framing Energy Sustainability in the Time of Renewables, pp. 119-145, London: Springer, 2017, p. 140.

${ }^{50}$ Benjamin K. Sovacool. An International Comparison of Four Polycentric Approaches to Climate and Energy Governance. Energy Policy, 39, 3832-3844 (2011), p. 3842/3843.

51 Idem, p. 3843. 
Finally, it is the local governments who come up with innovative steps and strategies to handle climate change ${ }^{52}$.

Energiewende (otherwise called Germany's Renewable Energy Revolution) is one of the most symbolic and progressive example of this reformist political program proposed using the polycentric approach to handle climate change and energy transition. Its objective is to reframe Germany's fossil-based and nuclear energy systems driving them towards utilizing renewable and efficient energy sources utilizing the active involvement of the local communities so as to minimize the greenhouse gas emissions and open up a safe way for sustainable development in the future.

A few scholars indicated that Energiewende was important as a case study for research to introduce changes in the infrastructure of the governing body, from a polycentric viewpoint. They argued that Germany's energy transition offers one of the exceptional moments when social scientists can explore the dynamics of empirical phenomena in real time, setting up lab-type situations to investigate the emergence, success or possible failure of several steps in the governance of the energy infrastructure ${ }^{53}$.

Definitely, the rationale underlying Germany's radical policy to remodel its energy system which the Merkel administration suddenly and abruptly took control of just after the Fukushima (Japan) nuclear disaster of 2011, includes both climate protection and environmental sustainability. It also embraces the minimization of energy imports, high-tech growth and unemployment in order to assure its quota in a burgeoning global market for renewable energy sources and energy efficient technologies. The regional and local governments in particular, are steadily depending more on renewable energy technologies to decrease their energy dependence, buttress the creation of local value and secure employment ${ }^{54}$.

From the time the Act on the Supply of Electricity from Renewable Energy Sources into the Grid (Stromeinspeisungsgesetz, StrEG) was instituted

\footnotetext{
${ }^{52}$ Harriet Bulkeley and Michele Betsill. Rethinking Sustainable Cities: Multilevel Governance and the Urban Politics of Climate Change. Environmental Politics 14, 42-53 (2005), p. 45.

53 Andreas Goldthau. Rethinking the Governance of Energy Infrastructure: Scale, Decentralization and Polycentrism. Energy Research and Social Science, 1, p. 134-140 (2014), p. 139

54 Leslie Quitzow, Weert Canzler, Philipp Grundmann, Markus Leibenath, Timothy Moss, Tilmann Rave. The German Energiewende - What's happening? Utilities Policy, vol. 41, 163171 (2016), p. 164
} 
in 1990, the power agencies in the private sector needed to pay a minimum fee for third-party electricity generated in their regions of supply. This was the basis for the 'renewable energy sources' market to begin developing in Germany. However, this Act failed to boost the sector because the compensation rates were linked to the average prices of electricity which ended up making the renewables more unprofitable, and negatively impacting the scope for investing and developing this market ${ }^{55}$.

Therefore, to once again motivate the development of the renewable energy sources, the StrEG needed to be replaced. Also, the payments had to be decoupled from the current electricity price, which culminated in the launch of the Act on Granting Priority to Renewable Energy (or Renewable Energy Act, EEG). This Act which was implemented in 2000, introduced fixed feed-in tariffs for electricity drawn from renewable sources. Therefore, the grid operators had to receive electricity from third-party renewables to supply the electricity and pay the prices that had been fixed ${ }^{56}$.

Germany's Energiewende is thus under the control of the EEG and its amendments. This stimulated such a powerful inducement for the growth of most of the different technologies dealing with the renewables through an enormous business incentive, particularly for the private, small-scale energy entrepreneurs (private citizens, energy cooperatives and farmers) that, by 2014 , nearly half of the renewable energy used had been produced in Germany. Another important bill that was passed is the Federal Energy Concept that draws up medium to long-term goals to decrease the greenhouse gas emissions declaring that the Germany's present energy system, which is still largely reliant on nuclear power, oil, coal and gas will, by the year 2050, shift to depend more on renewable energy resources (like wind power, solar energy, hydropower, biomass and geothermal energy $)^{57}$.

The Energiewende, from the perspective of governance, was designed for implementation in a multi-level system using a complex process which included the polycentric approach and involving various players and institutions. This presents vast scope for consolidating the role of the German states,

55 Jürgen-Friedrich Hake, Wolfgang Fischer, Sandra Venghaus, Christoph Weckenbrock. The German Energiewende - History and Status Quo. Energy, 92, 532-546 (2015), p. 539.

56 Idem, p. 540.

${ }^{57}$ Cit., p. 164. 
regions and municipalities and endowing them with a significant aura of autonomy to act independently. Therefore, the progressive favorable results of the Energiewende are dependent upon robust collaborative work, particularly, at the lower levels which, as stated prior, frequently include the use of "trust catalysts". They also involve pioneering operations in a polycentric enterprise within the regional energy networks, bio-energy villages, 100\% renewable municipalities, newly established energy cooperatives, financing of renewable power plants by the citizens and other endeavors that propel the concepts of the Energiewende ${ }^{58}$.

Moreover, by concentrating its works in the re-municipalization of the energy system via renewable sources, the Energiewende generates added value for the citizens in lieu of privatizing profits, offering the perfect opportunity to regulate the power supply in small decentralized units. This guarantees a high level of security of supplies as well as, simultaneously, achieves further targets like control of climate change, economic sustainability and social responsibility ${ }^{59}$.

Certainly, this complex process has encountered a series of criticisms and includes issues that need to be held in balance and assessed, for instance, the disparity in income and opportunity distribution precipitated by the Energiewende. According to Ortwin Renn and J. P. Marshall while above 40,000 private solar energy producers can benefit from a guaranteed income generated by selling electricity (which far exceeds the present interest rates on capital), the poorer sectors of society will need to pay these fixed prices. This has stirred up some disillusionment regarding the Energiewende, apart from a regretful recollection of the "golden age" of coal. The straightforward lesson learned from history is the need for readiness to deal with the paradoxical effects and unexpected backlashes of the policy ${ }^{60}$.

From a logical standpoint, a polycentric approach to climate governance simultaneously includes experiments which have succeeded and failed. In both cases, one must remember that both can promote innovation, and positively

\footnotetext{
58 Sonnenschein, J. and Hennicke, P. (eds) The German Energiewende. A Transition towards an efficient, sufficient Green Energy Economy. International Institute for Industrial Environmental Economics, Lund University (2015), p. 68.

59 Idem, p. 69.

${ }^{60}$ Ortwin Renn and Jonathan Paul Marshall. Coal, Nuclear and Renewable Energy Policies in Germany: From the 1950s to the "Energiewende". Energy Police, 99, p. 224-232 (2016), p. 231.
} 
affect the entire climate system through the processes of knowledge acquisition and learning, as explained by Ostrom. Commenting on the Energiewende, Marcel J. Dorsch and Christina Flatchsland confirmed that this enterprise was not a single enormous experiment but a gradual incremental process which involved several technological and political tests and trials. It required both the failures of these experiments along with the successes to nurture innovation and knowledge, as well as policy and technology transfer and continued adaptation of the various designs of governance ${ }^{61}$,

Germany's Renewable Energy Revolution has been an inspiration to the local communities to implement their own systems of renewable energy supply, backed by the lower levels of governance. Recently, in Barcelona, Spain there has been another fascinating enterprise of the polycentric approach to climate governance and the energy system.

The local government of Barcelona city set up in 2015, the Barcelona Local Energy Agency, a public agency with the objective of generating and trading electricity apart from providing energy supply from renewable sources for the Municipal Institutions, thus advocating the decentralization of the energy produced away from the private sector power companies and to the local community.

The underlying concept upholding this enterprise was to strengthen the Barcelona's environmental policies to operate according to the principles of sustainable development presented in The Energy, Climate Change and Air Quality Plan of Barcelona, 2011-2020, and the Citizen Commitment to Sustainability, 2012-2022: "For a More Equitable, Prosperous and SelfSufficient Barcelona" which could be stipulated as its "Local Agenda 21".

Adhering to the terms of the Earth Summit (1992) in Rio de Janeiro, as well as to the Aalborg Charter (1995), Barcelona implemented the concept of "Local Agenda 21". The city council first approved "Local Agenda 21" with a tactical document "Citizen Commitment for Sustainability, 2002-2012"62. The "Citizen Commitment for Sustainability, 2012-2022" includes the updated

61 Marcel J. Dorsch and Christian Flatchsland. A Polycentric Approach to Global Climate Governance. Global Environmental Politics, Vol. 17, Number 2, 45-64 (2017), p. 56.

62 Laura Calvet-Mir and Hug March. Crisis and Post-crisis Urban Gardening Initiatives from a Southern European Perspective: The Case of Barcelona. European Urban and Regional Studies, Sage Journals, 1-16 (2017), p. 04 
version of Barcelona's " Local Agenda 21", instituting a set of principles linked to "good green governance" of this city. Among these principles, one can recognize the question related to resilience and global responsibility, which declares the necessity to respond to global actions within their own energy selfsufficiency limits, thus boosting the contribution of local renewable energy to warrant the supply ${ }^{63}$.

Other crucial international documents and institutions that could be best appreciated as a set of overarching rules that bind and ensure the coordination of the actions of the Barcelona Local Energy Agency include: Agenda 21, the Rio Declaration on Environment and Development and the Statement of Principles for the Sustainable Management of Forests (1992); the Aalborg Charter (1994) that involves an urban sustainability enterprise initiated by those who participated in the first European Conference on Sustainable Cities and towns; the Johannesburg World Summit on Sustainable Development (2002); and finally, the European Union Covenant of Mayors for Climate and Energy which received approval in 2008 with the objective of getting the local governments to voluntarily commit to and participate in realizing and surpassing the climate and energy goals of the EU.

Thus, the Barcelona Local Energy Agency endorses the city as a benchmark for handling energy efficiency and the way it affects the environment and climate system. The Barcelona's Municipality states, "through consensus and participation, the agency works to ensure the city achieves optimum standards in its use and management of local energy resources and promote quality, rational, sustainable energy demand"64.

Evidently, a few legal barriers and conflicts of interests are observed with the big private sector power companies that distribute the electricity at the national level, because the initiative also intends to target the users. The goal of the Barcelona Local Energy Agency is to supply sustainable energy services to roughly 20,000 families, in 2019.

Apart from the investments made in green energy transition, the Barcelona's Municipality hopes to cut its budget by nearly 500,000 euros and

63 Barcelona City Council. Compromís Ciutadà per a la Sostenibilitat (Citizen Commitment for Sustainability 2012-2022). Barcelona: Ajuntament de Barcelona, 2012.

64 The Barcelona Energy Agency. Available at: http://www.bcn.cat/climatechange/en/energia. 
lower its electricity consumption by $10 \%$. Further, the citizens will be able to produce and trade energy from several renewable sources through this agency, thus involving and driving them to practice pro-environmental behavioral patterns.

The Energiewende and Barcelona policies on green and secure energy supply signify that the polycentric approach reinforced by the decentralization of common-pool resources and public goods management can be an innovative method to overcome climate change and global warming, accomplished through a complex process that involves multi-level governance with the active involvement of community in an atmosphere of cooperation to handle global issues.

\section{Conclusion}

Hardin's theory revealed that the "Tragedy of Commons" includes a reductionism whose objective is to devalue the collective management of the common pool resources, based on the concept that the individual's interests always overshadow the consciousness connected to the limited availability of the natural resources present. Hardin argued that the culmination of this process is irreversible ruin. The only way to resolve the situation is to transform the common pool resources in terms of property rights and control their access through governmental measures and coercive means of protection.

On analyzing the experimental data, Ostrom's theory clearly challenges the prior concept, by highlighting the importance of self-governance of the common pool resources via collective actions. The objective here is to circumvent Hardin's logic of exclusion and instead to offer a systematic, enduring and sustainable utilization of the resources listed, within the active involvement of the local institutions and citizens.

In this setting, polycentricity looks like a viable alternative with a pluralistic method of governance of the common pool resources that extends well beyond the traditional economic theories built on the State and Market. The polycentric method focuses on the action of the multiple and lower levels as an analytical tool to determine global change, operating via independent and overlapping jurisdictions, through experimentation, learning, trust-building and sensitivity. 
From a logical perspective, the activity of the local communities emerge as the decisive factor that determines the success or failure of the governance of the common pool resources, from a polycentric approach, particularly, in terms of climate change. However, as the global level negotiations failed to make a strong plea to minimize the gaseous greenhouse emissions, high degrees of distrust resulted in such methods and, therefore, concerns regarding their efficiency were raised. Also, as the time factor is crucial in this context, the need of the hour is to speedily implement political steps to control the climate crisis.

Managing the issue of climate change via a polycentric approach involves raising the individual's degree of trust and reciprocity. Such governance focused on the small- to medium-scale units to enable open access to information networks and maintain the level of monitoring within the collective actions. The polycentric approach for climate change control offers wide scope for experimentation, selection and learning, guaranteeing innovation, adaptation, trustworthiness and cooperation via self-governing means.

The logic undergirding the Paris Agreement proposed for global climate governance reveals the acceptance of the polycentric approach. Its bottom-up process of voluntary mitigation initiatives performed through Nationally Determinate Contributions (NDC) builds the confidence levels of the countries as they are offered the chance to determine their own targets construct coordinate linkages among the various levels of governance supplied by the global climate system and be able to work towards a common objective, which is to control the current climate crisis.

Inevitably, much criticism has been levied against the polycentric approach, specifically in terms of the likelihood of the fragmentation of the system and the absence of coordination among the different levels of governance, precipitating potential problems among them. From this perspective, it must be explained that at this point the polycentric approach regards the State as the central authority, the pivotal factor that plays a supportive role, by arbitrating and investing in decisive actions and dividing its powers with the different levels of governance available in the climate system.

At any rate, the polycentric approach directs its activities towards a merging of plans embraced by an overarching set of regulations so as to 
encourage the coordination of the entire system, increasing to its utmost the potential of the several institutions involved in managing climate change. To a lesser degree, the polycentric mode fosters research and laboratory experimentations, resulting in innovative projects that become models for other jurisdictions at the same or different levels. This process highlights the benefits of utilizing the local knowledge and learning from others, to ultimately construct a sustainable and resilient framework.

The Energiewende or Germany's Renewable Energy Revolution whose objective is to redirect the country's energy system towards green energy utilizing the active cooperation of the local communities, includes successful case studies that explore the dynamics of the polycentric approach, as it was intended to be executed through a multi-level system with the involvement of clearly-defined actors and institutions. The recent launch of the Barcelona Local Energy agency also showed that the polycentric initiatives in energy transition are highly relevant in handling climate change.

Finally, the polycentric approach suggests an ideal system of governance. In this light, although it includes elements from the hierarchical and monocentric systems, polycentricity involves action that is happening in the battle against climate change. Climate governance constructed on a polycentric approach has one huge benefit: the successful experiments, as well as the failures, both play roles in this process, as both can encourage innovation and positively impart support to the entire global climate system, with the processes of acquiring knowledge and learning.

\section{References}

AXELROD, Robert. Review: Beyond the Tragedy of the Commons. A Discussion of Governing the Commons: The Evolution of Institutions for Collective Action by Elionor Ostrom, in Perspectives on Politics, vol. 8, n. 02, 569-593, 2010.

BARCELONA CITY COUNCIL. Compromís Ciutadà per a la Sostenibilitat (Citizen Commitment for Sustainability 2012-2022). Barcelona: Ajuntament de Barcelona, 2012. 
BASURTO, Xavier and OSTROM, Elinor. The Core Challenges of Moving Beyond Garret Hardin, in Journal of Natural Resources Policy Research, vol. 01, n. 03, 255-259, 2009.

BAUWENS, Thomas. Polycentric Governance Approaches for a Low-Carbon Transition: The Roles of Community-Based Energy Initiatives in Enhancing the Resilience of Future Energy Systems, In Labanca, N. (ed), Complex Systems and Social Practices in Energy Transitions: Framing Energy Sustainability in the Time of Renewables, pp. 119-145, London: Springer, 2017.

BODANSKY, Daniel, BRUNÉE, Jutta and RAJAMANI, Lavanya. International Climate Change Law. Oxford University Press, 2017.

BULKELEY, Harriet and BETSILL, Michele. Rethinking Sustainable Cities: Multilevel Governance and the Urban Politics of Climate Change, in Environmental Politics, num. 14, 42-53, 2005.

CALVET-MIR, Laura and MARCH, Hug. Crisis and Post-crisis Urban Gardening Initiatives from a Southern European Perspective: The Case of Barcelona. European Urban and Regional Studies, Sage Journals, 1-16, 2017.

CLANCY, Erin A. The Tragedy of the Global Commons, in Indiana Journal of Global Legal Studies, num. 5, 601-619, 1998.

COLE, Daniel H. Advantages of a Polycentric Approach to Climate Change Policy, in Nature Climate Change, vol. 05, 2015.

DORSCH, Marcel J. and FLATCHSLAND, Christian Flatchsland. A Polycentric Approach to Global Climate Governance, in Global Environmental Politics, Vol. 17, Number 2, 45-64, 2017.

FALKNER, Robert Falkner. The Paris Agreement and the New Logic of International Climate Politics, in International Affairs, num. 92, 1107-112, 2016. FENNY, David, BERKES, Fikret, MCCAY, Bonnie J. and ACHESON, James M. The Tragedy of the Commons: Twenty-Two Years Later, vol. 18, Human Ecology, 02-19, 1990.

GILLARD, Ross, GOULDSON, Andrew, PAAVOLA, Jouni and VAN ALSTINE, James. Can national blockages accelerate the development of polycentric governance? Evidence from climate change policy in the United Kingdom. Global Environmental Change, num. 45, 174-182, 2017. 
GOLDTHAU, Andreas. Rethinking the Governance of Energy Infrastructure: Scale, Decentralization and Polycentrism. Energy Research and Social Science, num. 1, 134-140, 2014.

GONZALES REYES, L. Bienes Comunes, in Zubizarreta, J. H., González, E. y Ramiro, P. Diccionario Crítico de Empresas Transnacionales. Claves para enfrentar el Poder de las Grandes Corporaciones. Barcelona: Icaria Editorial, 2012.

HARDIN, Garrett. The Tragedy of the Commons, in Science 1243, 1968, reprinted in Fred P. Bosselman, Replaying the Tragedy of the Commons, 13, Yale J. on Reg. 391.

HAKE, Jürgen-Friedrich, FISCHER, Wolfgang, VENGHAUS, Sandra and WECKENBROCK, Christoph. The German Energiewende - History and Status Quo. Energy, num. 92, 532-546, 2015.

JÄNICKE, Martin. Accelerators of global energy transition: horizontal and vertical reinforcement in multi-level climate governance. Potsdam: Institute for Advanced Sustainability Studies, 2013.

JORDAN, Andrew, HUITEMA, Dave, SCHOENEFELD, Jonas, VAN ASSELT, Harro and FORSTER, Johanna. Governing Climate Change: Polycentricity in Action? Cambridge University Press, 2018.

JÖRGENSEN, Kirsten, JOGESH, Anu and MISHRA, Arabinda. Multi-level Climate Governance and the Role of the Subnational Level, in Journal of Integrative Environmental Sciences, 12:4, 235-245, 2015.

KEOHANE, Robert O. and VICTOR, David G. Cooperation and Discord in Global Climate Policy, in Nature Climate Change, num. 6, 2016.

MERINO PÉREZ, L. Perspectivas sobre la Gobernanza de los Bienes y la Ciudadanía en la Obra de Elinor Ostrom, in Revista Mexicana de Sociología n. 76 (especial), 77-104, 2014.

MOORE, J. A. Moore. Science as a Way of Knowing - Human Ecology, in American Zoologist, num. 25, 483-637, 1985.

OBERTHÜR, Sebastian. Reflections on global climate politics post Paris: Power, Interests and Polycentricity. The International Spectator, 51(4), 80-94, 2016.

OSTROM, Elinor. "Tragedy of the Commons" in The New Palgrave Dictionary of Economics. S. Durlauf \& L. Blume, eds. New York: Plagrave Macmillan, 2008. 
. Governing the Commons: The Evolution of Institutions for Collective Action, Cambridge University Press, New York, 1990.

. Common-Pool Resources and Institutions Toward a Revised Theory, in Handbook of Agricultural Economics, vol. 02, Edited by B. Gardner and G. Rauser, 2002.

. Beyond Markets and States: Policentric Governance of Complex Economic Systems, in American Economic Review, num. 100, 641-672, 2010.

. Polycentric Systems for Coping with Collective Action and Global Environmental Change, in Global Environmental Change, num. 20, 550-557, 2010.

A Polycentric Approach for Coping with Climate Change. Policy Research Working Paper 5095, World Bank, 200.

A Multi-Scale Approach to Coping with Climate Change and Other Collective Action Problems. Solutions 1 (2): 27-36 (2010).

OSTROM, Vicent, TIEBOUT, Charles M. and WARREN, Robert. The Organization of Government in Metropolitan Areas: A Theoretical Inquiry, in American Political Science Review, num. 55 (4), 831-842, 1961.

. Polycentricity - Part I, in Polycentricity and Local Public Economics.

Ed. Michel Mc Ginis, 52-74. Ann Arbor: University of Michigan Press, 1999.

QUITZOW, Leslie, CANZLER, Weert, GRUNDMANN, Philipp, LEIBENATH, Markus, MOSS, Timothy and RAVE, Tilmann. The German Energiewende What's happening?, in Utilities Policy, vol. 41, 163-171, 2016.

RAMOS OLIVOS, A. El Concepto de Bienes Comunes en la Obra de Elinor Ostrom, in Ecología Política, num. 45, 116-121, 2013.

RENN, Ortwin and MARSHALL, Jonathan Paul. Coal, Nuclear and Renewable Energy Policies in Germany: From the 1950s to the "Energiewende". Energy Police, 99, 224-232, 2016.

RODGERS, Christopher. Reversing the Tragedy of the Commons - Sustainable Management and the Commons Act 2006, in Modern Law Review, num. 73, 461-486, 2010.

SONNENSCHEIN, J. and HENNICKE, P. (eds) The German Energiewende. A Transition towards an efficient, sufficient Green Energy Economy. International Institute for Industrial Environmental Economics, Lund University, 2015. 
SOVACOOL, Benjamin K. An International Comparison of Four Polycentric Approaches to Climate and Energy Governance, in Energy Policy, num. 39, 3832-3844, 2011.

TOSUN, Jale and SCHOENEFELD, Jonas. Collective Climate Action and Networked Climate Governance. WiREs Clim Change 2017, 8: e440.

WALKER, James M., GARDNER, Roy, HERR, Andrew Herr and OSTROM, Elinor, Collective Choice in the Commons: Experimental Results on Proposed Allocation Rules and Votes, in The Economic Journal, 110, 212-234, 2000. 